\title{
PENINGKATAN HASIL BELAJAR SISWA MELALUI PENERAPAN MODEL PEMBELAJARAN KOOPERATIF TIPE STAD PADA MATA PELAJARAN MATEMATIKA KELAS IV SD NEGERI 040475 JANDIMERIAH
}

\author{
Sempurna \\ Surel: narukenovriana@yahoo.com
}

\begin{abstract}
ABSTRAK
Penelitian ini bertujuan untuk meningkatkan hasil belajar dan aktivitas belajar siswa melalui Model Pembelajaran Student Teams Achievement Devision (STAD). Subjek penelitian adalah siswa kelas IV berjumlah 29 orang. Data hasil belajar pada siklus I menunjukkan 21 orang tuntas. Pada siklus II, 26 orang tuntas dengan ketuntasan klasikal 89,65\%. Rata-rata siklus I dan II yaitu 76,55 dan 84,13. Berarti siklus II tuntas sesuai dengan KKM Matematika dengan ketuntasan klasikal 89,65\%. Data aktivitas siswa pada siklus I antara lain menulis/membaca (44\%), bekerja (20\%), bertanya sesama teman $(9 \%)$, bertanya kepada guru $(5,5 \%)$, dan yang tidak relevan dengan KBM (21,5\%). Data aktivitas siswa pada siklus II antara lain menulis/membaca (25\%), bekerja $(39,5 \%)$, bertanya sesama teman $(16,5 \%)$, bertanya kepada guru (15\%), dan yang tidak relevan dengan KBM (4\%).
\end{abstract}

Kata Kunci ; Hasil Belajar, Model Pembelajaran, STAD

\section{PENDAHULUAN}

Peran guru sebagai fasilitator adalah memfasilitasi proses pembelajaran yang berlangsung di kelas. Guru memilih atau merancang rencana pembelajaran yang sesuai dengan kondisi kelas dan berusaha mengarahkan siswa untuk berperan aktif dan bertanggung jawab terhadap proses serta hasil pembelajaran.

Berdasarkan pengalaman peneliti selama mengajar matematika di SD Negeri 040495 Jandimeriah terdapat beberapa masalah yaitu proses pembelajaran di kelas tersebut berlangsung hanya sebatas guru menerangkan dan siswa mendengarkan kemudian mencatat pelajaran yang diberikan. Media yang digunakan dalam pembelajaran hanya sebatas papan tulis, tidak terdapat media tambahan lain yang mendukung proses pembelajaran. Pembelajaran matematika dianggap sulit oleh siswa sehingga ketika guru bertanya pada siswa, tak satupun siswa memberikan tanggapannya, hasil belajar siswa pada bidang studi matematika masih di bawah ratarata, belum memenuhi KKM.

Permasalahan tersebut menunjukkan bahwa siswa kurang terlibat dalam proses pembelajaran seperti diskusi kelompok, bertanya, mengerjakan tugas, memperhatikan penjelasan guru, meringkas materi, dan mengerjakan soal-soal. Hal tersebut mengindikasikan bahwa minat siswa belajar matematika siswa masih rendah. Pelajaran matematika tidak hanya dikuasai dengan mendengarkan dan mencatat saja, masih perlu lagi interaksi guru dengan siswa dalam kegiatan lain seperti 
bertanya, mengerjakan latihan, mengerjakan pekerjaan rumah (PR), maju ke depan kelas, mengadakan diskusi, serta mengeluarkan ide atau gagasan. Hal ini berkaitan dengan metode yang digunakan guru dalam proses pembelajaran tersebut. Metode yang digunakan guru dalam proses pembelajaran kurang dapat meningkatkan daya ingat siswa untuk belajar matematika sehingga aktivitas dan hasil belajar siswa masing sangat rendah.

Guru dapat memilih dan menggunakan beberapa metode pembelajaran, dimana metode pembelajaran yang dipakai dapat menarik perhatian siswa sehingga dapat meningkatkan minat dan daya ingat belajar siswa. STAD (Student Team Achievement Division) merupakan salah satu metode pembelajaran kelompok yang paling awal ditemukan. Metode ini sangat populer dikalangan para ahli pendidikan. Dalam metode STAD siswa dipasangkan secara merata yang memiliki kemampuan tinggi dan rendah dalam suatu kelompok sebanyak 4-5 orang. Skor kelompok diberikan berdasarkan atas keaktifan anggota kelompoknya. Ciri-ciri yang penting dalam STAD adalah bahwa siswa dihargai atas pendapat kelompok dan juga terhadap semangat kelompok untuk bekerjasama.

Pembelajaran kooperatif tipe STAD terdiri dari lima komponen utama, yaitu: pengajaran kelas, belajar time tes atau kuis, skor peningkatan individu dan pengakuan kelompok (Slavin, 2005).

Tabel Langkah - Langkah Model Pembelajaran Kelompok STAD

\begin{tabular}{|c|c|}
\hline Fase & Laku \\
\hline $\begin{array}{c}\text { Fase }-1 \\
\text { Menyampai- } \\
\text { kan tujuan } \\
\text { dan } \\
\text { memotivasi } \\
\text { siswa }\end{array}$ & $\begin{array}{lr}\text { Guru menyampaikan } \\
\text { semua } & \text { tujuan } \\
\text { pelajaran } & \text { yang } \\
\text { dicapai } & \text { pada } \\
\text { pelajaran } & \text { tersebut } \\
\text { dan } & \text { memotivasi } \\
\text { siswa belajar. }\end{array}$ \\
\hline $\begin{array}{c}\text { Fase }-2 \\
\text { Menyajikan } \\
\text { informasi }\end{array}$ & $\begin{array}{l}\text { Guru menyajikan } \\
\text { informasi kepada } \\
\text { siswa dengan jalan } \\
\text { demonstrasi atau } \\
\text { lewat bahan bacaan. }\end{array}$ \\
\hline $\begin{array}{c}\text { Fase }-3 \\
\text { Mengorgani- } \\
\text { sasikan siswa } \\
\text { kedalam } \\
\text { kelompok } \\
\text { kooperatif }\end{array}$ & $\begin{array}{lr}\text { Guru menjelaskan } \\
\text { kepada } & \text { siswa } \\
\text { bagaimana } & \text { caranya } \\
\text { membentuk } & \\
\text { kelompok belajar dan } \\
\text { membantu } & \text { setiap } \\
\text { kelompok } & \text { agar } \\
\text { melakukan } & \text { transisi } \\
\text { secara efisien. } & \end{array}$ \\
\hline $\begin{array}{c}\text { Fase }-4 \\
\text { Membimbing } \\
\text { kelompok } \\
\text { bekerja dan } \\
\text { belajar }\end{array}$ & $\begin{array}{l}\text { Guru membimbing } \\
\text { kelompok-kelompok } \\
\text { belajar pada saat } \\
\text { mereka mengerjakan } \\
\text { tugas mereka. }\end{array}$ \\
\hline $\begin{array}{l}\text { Fase }-5 \\
\text { Evaluasi }\end{array}$ & $\begin{array}{l}\text { Guru mengevaluasi } \\
\text { hasil belajar tentang } \\
\text { materi yang telah } \\
\text { dipelajari atau } \\
\text { masing-masing } \\
\text { kelompok } \\
\text { mempresentasikan } \\
\text { hasil kerjanya }\end{array}$ \\
\hline $\begin{array}{r}\text { Fase }-6 \\
\text { Memberika }\end{array}$ & $\begin{array}{l}\text { Guru mencari cara- } \\
\text { cara untuk }\end{array}$ \\
\hline
\end{tabular}




\begin{tabular}{|c|c|}
\hline penghargaan & $\begin{array}{l}\text { menghargai baik } \\
\text { upaya maupun hasil } \\
\text { belajar individu atau } \\
\text { kelompok }\end{array}$ \\
\hline
\end{tabular}

\section{METODE PENELITIAN}

Lokasi penelitian ini dilakukan di Desa Jandimeriah Kec. Tiganderket. Materi Pembelajaran yang diterapkan selama pengambilan data adalah sifat-sifat operasi bilangan di kelas IV SD Negeri 040495 Jandimeriah. Penelitian ini dilaksanakan mulai bulan September 2013 sampai dengan Desember Tahun 2015. Subjek dalam penelitian ini yaitu kelas IV SD Negeri 040475 Jandimeriah sebanyak 29 orang.

Penelitian ini menggunakan Penelitian Tindakan Kelas (PTK). PTK adalah suatu bentuk kajian yang bersifat reflektif oleh pelaku tindakan yang dilakukan untuk meningkatkan kemantapan rasional dari tindakan mereka dalam melaksanakan tugas.

Penelitian Tindakan Kelas (PTK) yaitu penelitian tindakan, maka penelitian ini menggunakan model penelitian tindakan dari Kemmis dan Taggart (dalam Arikunto, 2002), yaitu berbentuk spiral dari siklus yang satu ke siklus yang berikutnya. Setiap siklus meliputi planning (rencana), action (tindakan), observation (pengamatan), dan reflection (refleksi). Langkah pada siklus berikutnya adalah perencanaan yang sudah direvisi, tindakan, pengamatan, dan refleksi. Sebelum masuk pada siklus 1 dilakukan tindakan pendahuluan yang berupa identifikasi permasalahan. Prosedur tersebut banyak diacu oleh guru dalam melaksanakan PTK dengan memuat bagan dalam Sani dan Sudiran (2012) sebagai berikut:

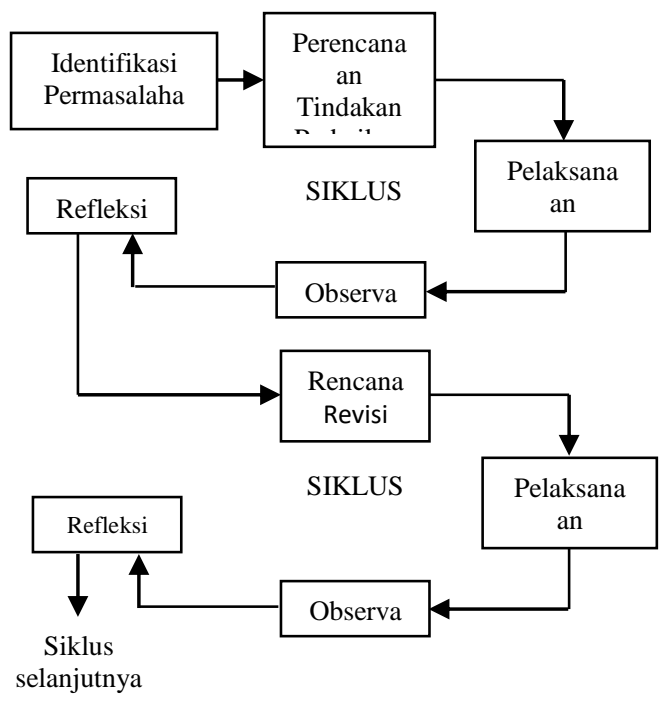

Gambar Siklus dalam prosedur PTK

Metode analisis data pada penelitian ini digunakan metode deskriptif dengan membandingkan hasil belajar siswa sebelum tindakan dengan hasil belajar siswa setelah tindakan.

Langkah-langkah pengolahan data sebagai berikut:

1. Merekapitulasi nilai pretes sebelum tindakan dan nilai tes akhir siklus I dan siklus II.

2. Menghitung nilai rata-rata atau persentase hasil belajar siswa sebelum dilakukan tindakan dengan hasil belajar setelah dilakukan tindakan pada siklus I dan siklus II untuk mengetahui adanya peningkatan hasil belajar.

3. Penilaian 
a. Data nilai hasil belajar (kognitif) diperoleh dengan menggunakan rumus:

Nilai Siswa $=\frac{\text { Jumlah jawaban benar }}{\text { Jumlah seluruh soal }} \times 100$

b. Nilai rata-rata siswa dicari dengan rumus sebagai berikut:

$$
\begin{aligned}
& \qquad \bar{X}=\frac{\sum X}{N} \\
& \text { Keterangan : } \\
& \bar{X}=\text { Nilai rata-rata } \\
& \Sigma=\text { Jumlah nilai } X \\
& \mathrm{~N}=\text { Jumlah peserta tes }
\end{aligned}
$$

c. Untuk penilaian aktivitas digunakan rumus sebagai berikut:

$\%$ aktivitas $=\frac{\text { Jumlah hasil pengamatan }}{\text { Jumlah pengamat }} \times 100$

\section{d. Ketentuan persentase} ketuntasan belajar kelas

Ketuntasan belajar kelas $=\frac{\sum \mathrm{S}_{\mathrm{b}}}{\mathrm{K}} \times 100 \%$

$\Sigma \mathrm{Sb}=$ Jumlah siswa yang mendapat nilai $\geq 65$ (kognitif)

$\Sigma \mathrm{K}=$ Jumlah siswa dalam sampel

\section{HASIL DAN PEMBAHASAN}

\section{Data Siklus I}

Pada tahap ini peneliti mempersiapkan perangkat pembelajaran yang terdiri dari RPP 1 dan 2, LKS 1 dan 2, soal tes formatif 1, dan alat-alat pengajaran dan media untuk mendukung kegiatan belajar mengajar.
Pelaksanaan

Pelaksanaan kegiatan belajar mengajar untuk siklus I dilaksanakan pada hari Selasa, tanggal 20 Oktober 2015 pada pertemuan I dan Kamis, tanggal 22 Oktober 2015 pada pertemuan II di kelas IV dengan jumlah siswa 29 siswa. Dalam hal ini peneliti bertindak sebagai guru. Adapun proses belajar mengajar mengacu pada rencana pelajaran yang telah dipersiapkan. Pengamatan (observasi) dilaksanakan bersamaan dengan pelaksanaan belajar mengajar.

Akhir siklus I dilakukan tes hasil belajar atau disebut formatif I, dengan data dapat dilihat pada tabel merujuk pada kesimpulan ini guru sebagai peneliti berusaha memperbaiki proses dan hasil belajar siswa melalui model pembelajaran kooperatif tipe STAD.

\begin{tabular}{|c|c|c|}
\hline Nilai & Frekuensi & Nilai rata-rata \\
\hline 60 & 8 & \\
\hline 80 & 18 & \\
\hline 100 & 3 & \\
\hline Jumlah & 29 & 76,55 \\
\hline
\end{tabular}
Hasil belajar yang diperoleh pada Siklus I selama dua pertemuan disajikan dalam Tabel berikut:

Tabel Distribusi Hasil Formatif I

Pada tabel di atas, nilai terendah Formatif I adalah 60 sebanyak 8 orang dan nilai tertinggi adalah 100 sebanyak 3 orang, dengan 8 orang mendapat nilai dibawah kriteria ketuntasan atau ketuntasan klasikal adalah sebesar 72,41\%, dengan nilai KMM sebesar 65. Nilai ini berada di bawah kriteria 
keberhasilan klasikal sehingga dapat dikatakan KBM Siklus I tidak berhasil memberi ketuntasan belajar dalam kelas. Nilai rata-rata kelas adalah 76,55. Data hasil Formatif I ini dapat disajikan kembali dalam grafik histogram sebagai berikut:

\section{Grafik Formatif I}

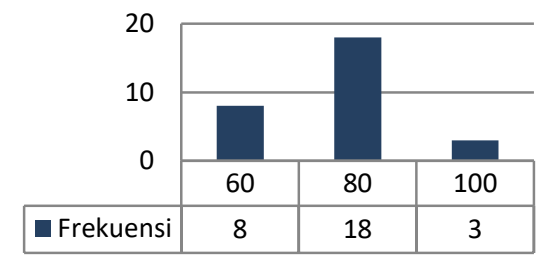

Gambar Grafik data hasil Formatif I

\section{Data Aktivitas Pada Siklus I}

Setelah guru selesai menyajikan materi pembelajaran, maka siswa disuruh bekerja berkelompok untuk mengerjakan LKS. Siswa bekerja dalam kelompok, peneliti memberikan instrument aktivitas siswa kepada pengamat. Untuk merekam aktivitas siswa dilakukan oleh dua pengamat sesuai dengan instruksi oleh peneliti. Kedua pengamat melakukan pengamatan selama 4 kali atau Siklus I dan Siklus II. Hasil rekaman yang dilakukan oleh kedua pengamat diserahkan kembali kepada peneliti. Hasil analisis rekaman aktivitas siswa dari kedua pengamat selama 4 kali dapat dilihat pada tabel di bawah ini:

Tabel Skor aktivitas belajar siswa

\begin{tabular}{|c|l|c|c|c|}
\hline \multicolumn{5}{|c|}{ Siklus I } \\
\hline No & Aktivitas & Jlh & $\begin{array}{l}\text { Rata- } \\
\text { Rata }\end{array}$ & Proporsi \\
\hline 1 & $\begin{array}{l}\text { Menulis } \\
\text {,membaca }\end{array}$ & 88 & 22 & $44 \%$ \\
\hline
\end{tabular}

\begin{tabular}{|c|l|c|c|c|}
2 & Mengerjakan & 40 & 10 & $20 \%$ \\
\hline 3 & $\begin{array}{l}\text { Bertanya pada } \\
\text { teman }\end{array}$ & 18 & 4,5 & $9 \%$ \\
\hline 4 & $\begin{array}{l}\text { Bertanya pada } \\
\text { guru }\end{array}$ & 11 & 2,75 & $5,5 \%$ \\
\hline 5 & $\begin{array}{l}\text { Yang tidak } \\
\text { relevan }\end{array}$ & 43 & 10,75 & $21,5 \%$ \\
\hline \multicolumn{2}{|l}{ Jumlah } & 200 & 50 & $100 \%$ \\
\hline
\end{tabular}

\section{Refleksi}

Berdasarkan data tabel distribusi hasil formatif I diperoleh bahwa rata-rata Formatif 76,55 pada Siklus I dengan persentase adalah $72,41 \%$. Hasil tersebut menunjukkan bahwa pada Siklus I secara klasikal siswa belum tuntas belajar, karena siswa yang memperoleh nilai $\geq 65$ hanya sebesar $72,41 \%$ lebih kecil dari persentase ketuntasan yang dikehendaki yaitu sebesar $85 \%$. Hal ini disebabkan karena siswa masih merasa baru dan belum mengerti apa yang dimaksudkan dan digunakan guru dengan menerapkan model pembelajaran kooperatif tipe STAD.

Belum tercapainya standar ketuntasan tersebut tidak terlepas dari rendahnya aktivitas belajar siswa. Merujuk pada Tabel aktivitas belajar siswa, pada Siklus I rata-rata aktivitas I yakni menulis dan membaca memperoleh proporsi $44 \%$. Aktivitas mengerjakan dalam diskusi mencapai $20 \%$. Aktivitas bertanya pada teman sebesar 9\%. Aktivitas bertanya kepada guru 5,5\% dan aktivitas yang tidak relevan dengan KBM sebesar 21,5\%. Aktivitas membaca memperoleh proporsi lebih besar dibandingkan aktivitas mengerjakan. Hal ini berarti siswa belum mempersiapkan diri dari rumah, 
sehingga pada saat diskusi siswa masih banyak yang membaca dibandingkan mengerjakan LKS. Pada proses pembelajaran masih ditemukan hal-hal yang perlu mendapatkan perhatian berkaitan dengan penelitian tindakan kelas yaitu:

a. Kemampuan kooperatif tipe STAD dalam kelompoknya masih kurang terlihat dari dokumentasi dan menonjolnya aktivitas menulis dan membaca (44\%) yang mengindikasikan sebagian besar siswa tidak memahami materi dan tidak tahu harus mendiskusikan apa.

b. Kekompakan kerja kelompoknya masih kurang terlihat dari aktivitas terlihat dari rendahnya proporsi aktivitas bertanya dengan teman dalam kelompok $(9 \%)$.

c. Dalam menyelesaikan tugas kelompok masih kurang terlihat dari aktivitas kerja yang rendah (20\%).

d. Suasana pembelajaran kurang kondusif terlihat dari aktivitas tidak relevan yang mencapai $21,5 \%$ yang cukup menonjol mengingat aktivitas ini seharusnya tidak perlu ada.

e. Siswa dalam menulis di papan tulis masih kurang terampil.

\section{Revisi}

Dari paparan deskripsi penelitian tindakan kelas siklus I, maka di dalam refleksi diupayakan perbaikan untuk meningkatkan proses pembelajaran dan aktivitas belajar siswa pada siklus
II, beberapa perbaikan pembelajaran dilakukan antara lain:

a. Pada Siklus II kelompok dibentuk kembali dengan mempertimbangkan komposisi siswa-siswa unggul sebagai kooperatif tipe STAD untuk meningkatkan kemampuan kooperatif tipe STAD dalam memberikan arahan dan memimpin kelompok

b. Tugas-tugas dikumpulkan dengan cara penagihan tiap individu ini untuk meningkatkan partispasi dan kemampuan siswa dalam menyelesaikan tugas

c. Dalam pembahasan materi ajar, guru menggunakan aturan seperti pada pertemuan sebelumnya, tetapi pada pembelajaran kali ini guru membenahi gaya mengajarnya seperti melakukan pendekatan kepada siswa yang kurang perhatian pada saat pelajaran berlangsung.

d. Guru juga memberikan kata-kata pujian, semangat agar siswa menjadi lebih aktif dan menimbulkan keberanian siswa mengerjakan tugas di depan kelas.

e. Dalam proses pembelajaran ini setiap siswa dilibatkan secara keseluruhan oleh guru. Para siswa harus memperhatikan guru saat memberikan penjelasan. Selain itu guru juga berkeliling memantau dan memberikan bimbingan kepada siswa yang mengalami kesulitan dalam menangkap inti pelajaran serta yang mengalami kesulitan dalam mengerjakan soal. 
f. Peneliti menginformasikan bahwa di akhir pertemuan Siklus II akan ada tes Formatif, dengan harapan agar siswa lebih aktif dalam belajar.

g. Melakukan patokan pada format analisis yang mengarahkan pada kesimpulan sehingga siswa dapat melakukan pengambilan kesimpulan secara runtun dan sistematis.

\section{Siklus II}

Perencanaan

Melihat hasil evaluasi belajar siklus I dimana yang tuntas belajar 21 siswa dari 29 siswa maka sebelum penelitian lanjutan siklus II dilaksanakan maka peneliti melakukan refleksi hasil siklus 1 . Refleksi ini bertujuan:

a. Memecahkan masalah dan kendala-kendala pada siklus I,

b. Membuat rancangan tindakan di siklus II,

c. Melakukan evaluasi terpadu terhadap peningkatan hasil belajar ranah kognitif dan afektif. Pertemuan ini menghasilkan langkah-langkah sebagai berikut adalah:

1) Melakukan persiapan dan menyusun pembuatan rancangan pengajaran yang lebih komprehensif pada siklus II.

2) Penelitian tindakan kelas siklus II tetap membutuhkan kerjasama rumpun mengingat penelitian ini tidak dapat berjalan dengan baik tanpa adanya dukungan dan kerjasama dari anggota rumpun.

3) Persiapan media dan sumber belajar juga dilakukan di siklus II misalnya buku paket, visualisasi gambar dan lain-lain. Pada siklus II penelitian tindakan kelas tetap memakai observer (pengamat), maka dibuat juga format observasi untuk memudahkan pengamat melakukan penilaian dan refleksi.

4) Pada tahap ini peneliti mempersiapkan perangkat pembelajaran yang terdiri dari rencana pelajaran 3 dan 4 , LKS 3 dan 4, soal tes formatif II, dan alat-alat pembelajaran dan media untuk mendukung kegiatan belajar mengajar.

Tahap kegiatan dan pengamatan

Pelaksanaan kegiatan belajar mengajar untuk siklus II dilaksanakan pertemuan 3 pada hari Selasa, tanggal 27 Oktober 2015 dan pertemuan keempat Hari Kamis, tanggal 29 Oktober 2015 di kelas IV dengan jumlah siswa 29 orang. Dalam hal ini peneliti bertindak sebagai guru. Adapun proses belajar mengajar mengacu pada rencana pelajaran dengan memperhatikan revisi pada siklus I, sehingga kesalahan atau kekurangan pada siklus I tidak terulang lagi pada siklus II. Pengamatan (observasi) dilaksanakan bersamaan dengan pelaksanaan belajar mengajar.

Data-data Formatif I dianalisis, sehingga mendapat suatu 
gambaran tentang keberhasilan siswa. Untuk memperbaiki hasil belajar siswa, peneliti memberikan suatu gambaran hasil belajar siswa pada Formatif I sesama peneliti/guru kemudian didiskusikan untuk mengambil tindakan berikutnya pada Siklus II. Diskusi tersebut juga dilakukan terhadap pembimbing PTK agar pada tindakan berikutnya aktivitas siswa semakin baik dan hasil belajarnya juga lebih baik.

Akhir KBM ke empat dilakukan tes hasil belajar atau disebut Formatif II, datanya dapat dilihat pada tabel di bawah ini.

Tabel Distribusi Hasil Formatif II

\begin{tabular}{|c|c|c|}
\hline Nilai & Frekuensi & Rata-rata \\
\hline 60 & 3 & \\
\cline { 1 - 2 } 80 & 17 & \\
\cline { 1 - 2 } 100 & 9 & \multirow{2}{*}{84,13} \\
\hline Jumlah & 29 & \\
\hline
\end{tabular}

Merujuk pada Tabel di atas, nilai terendah untuk Formatif II adalah 60 sebanyak 1 orang dan tertinggi adalah 100 sebanyak 9 orang. Dengan 3 orang mendapat nilai dibawah kriteria ketuntasan atau ketuntasan klasikal adalah sebesar $89,65 \%$. Nilai ini berada di atas kriteria keberhasilan sehingga dapat dikatakan KBM Siklus II berhasil memberi ketuntasan belajar dalam kelas. Nilai rata-rata kelas adalah 84,13. Data hasil Formatif II ini dapat disajikan kembali dalam grafik histogram sebagai berikut:

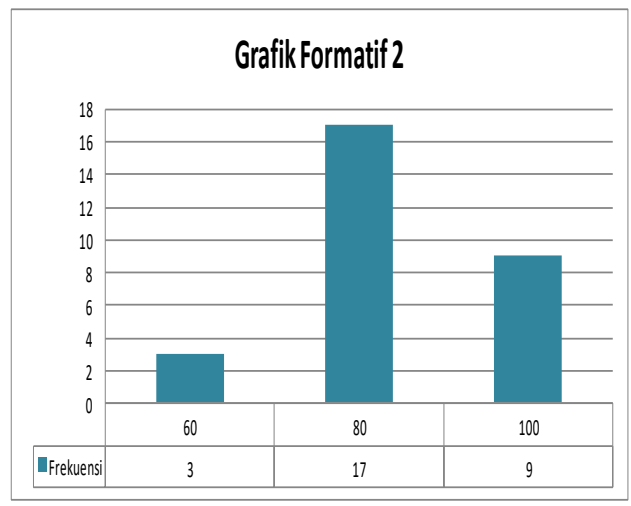

Gambar Grafik data hasil Formatif II

\section{Data Aktivitas Pada Siklus II}

Berdasarkan analisis data, diperoleh aktivitas siswa dalam proses pembelajaran matematika pada materi pelajaran Arus listrik yang paling dominan adalah aktivitas mengerjakan, bertanya kepada guru, dan diskusi antar siswa/antara siswa dengan guru. Jadi dapat dikatakan bahwa aktivitas siswa dapat dikategorikan aktif. Penskoran dilakukan dan dijabarkan dalam data berupa Tabel aktivitas oleh pengamat I dan II untuk Siklus II sebagai berikut:

Tabel Skor aktivitas belajar siswa

\begin{tabular}{|c|c|c|c|c|}
\hline \multicolumn{5}{|c|}{ Siklus II } \\
\hline No & Aktivitas & $\mathrm{Jlh}$ & $\begin{array}{l}\text { Rata- } \\
\text { Rata }\end{array}$ & $\begin{array}{l}\text { Propors } \\
\text { i }\end{array}$ \\
\hline 1 & $\begin{array}{l}\text { Menulis, } \\
\text { membaca }\end{array}$ & 50 & 12,5 & $25 \%$ \\
\hline 2 & Mengerjakan & 79 & 19,75 & $39,5 \%$ \\
\hline 3 & $\begin{array}{l}\text { Bertanya } \\
\text { pada teman }\end{array}$ & 33 & 8,25 & $16,5 \%$ \\
\hline 4 & $\begin{array}{l}\text { Bertanya } \\
\text { pada guru }\end{array}$ & 30 & 7,5 & $15 \%$ \\
\hline 5 & $\begin{array}{l}\text { Yang tidak } \\
\text { relevan }\end{array}$ & 8 & 2 & $4 \%$ \\
\hline & Jumlah & 200 & 50 & $100 \%$ \\
\hline
\end{tabular}




\section{Refleksi}

Hasil belajar siswa diakhir Siklus II telah mencapai ketuntasan klasikal $89,65 \%$, yang berarti hampir seluruh siswa telah memperoleh nilai tuntas dengan 3 orang siswa yang belum mendapatkan nilai di atas KKM. Dengan demikian tindakan yang diberikan pada Siklus II telah berhasil memberikan perbaikan hasil belajar pada siswa. Hal ini dipengaruhi beberapa faktor diantaranya adalah sebagai berikut:

a. Siswa sudah mulai terbiasa dengan bekerja secara kelompok.

b. Daya ingat belajar siswa sudah meningkat

c. Keberanian siswa untuk berinteraksi berjalan dengan baik karena siswa sudah mulai terbiasa untuk bertanya dan menyampaikan pendapatnya kepada sesama teman lainnya dalam menyelesaikan masalah.

d. Siswa mulai aktif dan tahu akan tugasnya sehingga tidak menggantungkan permasalahan yang dihadapi kepada teman dalam kelompoknya.

Pada Siklus II, pelaksanaan pembelajaran Kooperatif tipe STAD, tindakan berupa menampilkan media dan pemberian penugasan yang memunculkan banyak aktivitas sudah efektif.

Revisi Pelaksanaan

Pada siklus II guru telah menerapkan model pembelajaran Kooperatif tipe STAD dengan baik dan dilihat dari aktivitas siswa serta hasil belajar siswa pelaksanaan proses belajar mengajar sudah berjalan dengan baik. Maka tidak diperlukan revisi terlalu banyak, tetapi yang perlu diperhatikan untuk tindakan selanjutnya adalah memaksimalkan dan mempertahankan apa yang telah ada dengan tujuan agar pada pelaksanaan proses belajar mengajar selanjutnya penerapan pembelajaran Kooperatif tipe STAD dapat meningkatkan proses belajar mengajar sehingga tujuan pembelajaran dapat tercapai dengan maksimal.

\section{Pembahasan}

Merujuk pada hasil pretes, terdapat 8 siswa berada sesuai dengan KKM. Hal ini dapat diterima karena siswa memang belum belajar tentang materi sifat-sifat operasi bilangan. Dilakukannya pretes ini sebagai acuan tentang kemampuan awal siswa. Nilai rata-rata siswa saat pretes yaitu 59,66. Menunjukkan bahwa siswa tidak belajar dirumah sebelum mempelajari materi baru di sekolah atau dengan kata lain keinginan belajar siswa dirumah sangat rendah.

Di akhir pembelajaran siklus I dilakukan tes hasil belajar sebagai Formatif I. Merujuk pada Tabel 4.1 dengan KKM yang ditetapkan sebesar 65 maka 8 orang dari 29 siswa mendapat nilai dibawah kriteria ketuntasan atau ketuntasan klasikal adalah sebesar 72,41\%. Dengan kriteria ketuntasan klasikal $85 \%$, nilai ini berada di bawah kriteria ketuntasan tersebut sehingga dapat dikatakan KBM siklus I gagal 
memberi ketuntasan belajar dalam kelas. Nilai rata-rata kelas adalah 76,55. Sehingga untuk hasil belajar pada siklus I belum tuntas secara klasikal.

Merujuk pada Tabel tentang data Formatif II, nilai rata-rata meningkat menjadi 84,13. Sebanyak 3 orang siswa mendapat nilai dibawah kriteria ketuntasan atau ketuntasan klasikal adalah sebesar $89,65 \%$. Karena lebih dari $85 \%$ maka siklus II dikatakan tuntas meski menyisakan beberapa siswa yang memperoleh nilai tidak tuntas. Hal ini sesuai dengan pendapat Mulyasa. E (2000:99), yang menyatakan bahwa pengajaran dikatakan tuntas jika telah memenuhi ketuntasan belajar lebih dari $85 \%$.

Siklus II ini merupakan perbaikan dari siklus I, perbaikan ini dilakukan untuk meminimalkan permasalahan yang terjadi pada siklus I. Upaya yang dilakukan adalah dengan menampilkan beberapa media pembelajaran yang mempermudah siswa menafsirkan alur-alur materi pembelajaran, kemudian dengan cara memotivasi siswa agar aktif dan konsentrasi dalam setiap tahapan pada pengajaran STAD dan memberikan penghargaan kepada siswa yang berperan aktif dengan menambah poin nilai, baik secara individu maupun kelompok.

Aktivitas belajar siswa dan dokumentasi penelitian. Aktivitas pada siklus II telah lebih baik dari pada siklus I. Pada siklus II aktivitas individual menulis dan membaca mengalami penurunan proporsi menjadi $25 \%$. Pada siklus II tindakan yang diberikan mulai membuat siswa beradaptasi belajar dalam diskusi aktif dan aktivitas mengerjakan naik sedikit menjadi $47 \%$ pada siklus ini. Aktivitas bertanya pada teman dalam diskusi pada siklus II naik menjadi $16,5 \%$. Aktivitas-aktivitas yang tidak relevan pada siklus II turun menjadi sebesar $4 \%$ yang mengindikasikan pembelajaran sudah berjalan lebih kondusif.

Secara keseluruhan rangkaian proses penelitian dengan penerapan model pengajaran kooperatif tipe STAD pokok bahasan sifat-sifat operasi bilangan pada prinsipnya membantu untuk meningkatkan daya ingat belajar siswa dengan cara membuat pengajaran lebih menarik dan menyenangkan tidak monoton seperti sebelumnya. Dengan model pengajaran kooperatif tipe STAD dapat membuat pengajaran yang dilakukan lebih bervariasi, sehingga siswa akan termotivasi untuk belajar, selain itu guru dapat memantau dan mengidentifikasi sejauh mana keaktifan siswa. Guru dapat mengetahui siswa yang kurang aktif dalam kegiatan belajar mengajar untuk dapat menjadi aktif, sehingga akan berpengaruh baik pada peningkatan hasil belajar siswa tersebut.

\section{KESIMPULAN}

Data-data tes hasil belajar siswa dan aktivitas belajar siswa terhadap model pembelajaran kooperatif tipe STAD selama kegiatan belajar mengajar tersusun, kemudian 
dianalisis, sehingga dapat disimpulkan sesuai dengan rumusan masalah.

1. Hasil belajar siswa dengan menerapkan model pembelajaran kooperatif tipe STAD pada Formatif I dan Formatif II menunjukkan 21 orang siswa tuntas secara individu, sedangkan kelas tidak tuntas. Pada Siklus II, tuntas secara individu sebanyak 26 orang siswa, sedangkan kelas adalah tuntas dengan rata-rata siklus I dan siklus II adalah 76,55 dan 89,65 dengan ketuntasan klasikal sebesar $72,41 \%$ pada siklus I dan $89,65 \%$ pada Siklus II.

2. Data aktivitas siswa menurut kedua pengamatan pengamat pada Siklus I antara lain: menulis/membaca (44\%), bekerja (20\%), bertanya sesama teman (9\%), bertanya kepada guru $(5,5 \%)$, dan yang tidak relevan dengan KBM (21,5\%). Dan Data aktivitas siswa menurut pengamatan pada Siklus II antara lain: menulis/membaca (25\%), bekerja $(39,5 \%)$, bertanya sesama teman $(16,5 \%)$, bertanya kepada guru $(15 \%)$, dan yang tidak relevan dengan KBM (4\%).

Dari hasil yang diperoleh dalam penelitian ini, maka ada beberapa saran yang diajukan yaitu:

1. Diharapkan bagi guru memperhatikan pengetahuan awal, bakat dan kecerdasan yang dimiliki siswa sebelum pembelajaran diberikan.
2. Pemanfaatan LKS dapat digunakan guru-guru agar siswa termotivasi selama bekerja dalam kelompok.

3. Untuk melaksanakan model pembelajaran kooperatif tipe STAD memerlukan persiapan yang cukup matang, sehingga guru harus mampu menentukan atau memilih topik yang benar-benar bisa diterapkan dengan model kooperatif tipe STAD dalam proses belajar mengajar sehingga diperoleh hasil yang optimal.

\section{DAFTAR RUJUKAN}

Aqib, Zainal. (2006). Penelitian Tindakan Kelas. Bandung: Yrama Widya.

Dimyati, dan Mudjiono. (2006). Belajar dan Pembelajaran. Jakarta: PT Rineka Cipta.

Djamarah, Syaiful Bahri dan Aswan Zain. (2006). Strategi Belajar Mengajar. Jakarta: PT Rineka Cipta.

Kemmis, S. dan Mc. Taggart, R. 2002. The Action Research Planner. Victoria Dearcin University Press.

Sagala, S. (2009). Konsep Dan Makna Pembelajaran. Bandung: Alfabeta.

Sani, R.A. dan Sudiran. 2012. Meningkatkan

Profesionalisme Guru Melalui Penelitian Tindakan Kelas. Bandung: Citapustaka Media Perintis. 
Sempurna: Peningkatan Hasil Belajar Siswa ...

Slameto. (2003). Belajar dan Faktor-

Faktor

Yang

Mempengaruhinya. Jakarta:

Penerbit Rineka Cipta.

Slavin, R.E. 2005. Cooperative

Learning Teori, Riset, dan

Praktik. Bandung: Nusa

Media.

Trianto. (2007). Model-model

Pembelajaran Inovatif

Berorientasi Konstruktivistik.

Jakarta: Prestasi Pustaka

Publisher. 